\title{
Analysis of efficiency in under-16 basketball: A log-linear analysis in a systematic observation study \\ Análisis de la eficacia en baloncesto U16: aplicación del log-linear en metodología observacional
}

\footnotetext{
Faculty of Letters and Education. University of La Rioja, España

${ }^{2}$ Faculty of Psychology. University of Barcelona, España

*Correspondence: daniel.lapresa@unirioja.es
}

Roberto Alsasua ${ }^{1}$, Javier Arana ${ }^{1}$, Daniel Lapresa ${ }^{1 *}$, M. Teresa Anguera ${ }^{2}$
Received: 23 April 2021 / Accepted: 09 December 2022
HOW TO CITE THIS ARTICLE:

Alsasua, R., Arana, J., Lapresa, D., \& Anguera, M.T. (2022). Analysis of efficiency in under-16 basketball: A log-linear analysis in a systematic observation study. Cultura Ciencia y Deporte, 17(51), 105-112. http://dx.doi.org/10.12800/ccd.v17i51.1736.

\begin{abstract}
Within the framework of an observational methodology study, we used log-linear analysis to analyze efficiency in elite under-16 basketball from the perspective of three key dimensions: shot position, last pass position, and shot result. The reliability of the observational datasets was confirmed by analysis of interobserver agreement (Cohen's kappa statistic) and a generalizability theory analysis. The most parsimonious hierarchical model selected using backward elimination in the log-linear analysis was a conditional independence model where the association between last pass position and shot position was independent of shot result and the association between shot position and shot result was independent of last pass position. In this article, we discuss the results corresponding to the model's first- and second-order effects and show the possibilities offered by log-linear analysis within a systematic observation study to analyze efficiency in basketball.
\end{abstract}

Keywords: performance analysis, observational methodology, last pass position, shot position, shot result.

\section{Resumen}

En el seno de la metodología observacional se realiza un estudio de la eficacia en la élite del baloncesto sub 16. Mediante un análisis log-linear se analiza la asociación entre tres dimensiones claves en el estudio de la eficacia. En lo relativo a la calidad del dato, se ha garantizado la concordancia inter-observadores mediante el coeficiente kappa de Cohen. Además, en el seno de la teoría de la generalizabilidad, se ha garantizado una elevada fiabilidad de precisión de generalización de los resultados. Los resultados obtenidos a partir del análisis log-linear realizado muestran que el modelo jerárquico más parsimonioso seleccionado a través del procedimiento backward es el de independencia condicional: la asociación entre el lugar desde el que se realiza el último pase y el lugar desde el que se realiza el lanzamiento es independiente de consecuencia del lanzamiento; y la asociación entre el lugar desde el que se realiza el lanzamiento y la consecuencia del lanzamiento es independiente del lugar desde el que se realiza el último pase. A partir de la discusión de los resultados relativos a los efectos de primer y segundo orden se han constatado las posibilidades que el análisis loglinear brinda a la metodología observacional.

Palabras clave: análisis del rendimiento, metodología observacional, posición del último pase, posición en el lanzamiento, resultado del lanzamiento. 


\section{Introduction}

Studies of efficiency and factors that influence efficiency are common in elite basketball (Gómez et al., 2013; Izquierdo et al., 2021; Sampaio et al., 2010; Simovic et al., 2012, 2021). The most common performance indicator in this setting is shot success (Erculj \& Strumbelj, 2015; Ibáñez et al., 2009), which is analyzed in a wide range of contexts, including comparisons between winning and losing teams (Fernández \& Piñar, 2017; Gómez et al., 2008), home and away teams (Ribeiro et al., 2016), and league and playoff matches (García et al., 2013).

To better understand what occurs during a game of basketball, it is important not only to determine how and where shots are taken, but also to study the actions leading up to these shots (Oudejans et al., 2012; Romaris et al., 2012)

Analyses of shots and favorable shooting conditions are also important for training purposes (Lapresa et al., 2013; Ortega et al., 2006; Piñar et al., 2014), as data from real-life situations can help coaches establish technical and tactical goals to ease the transition from amateur/youth basketball to professional /senior basketball (Alsasua et al., 2018). Under 16 (U16) basketball is a highly relevant category in this sense ( Lorenzo et al., 2010; Monteiro et al., 2013; Ortega et al., 2007), as it is the bridge between categories where the focus is still very much on player development and categories where the focus is on preparing players for the transition to senior or professional basketball (e.g., U18/senior amateur teams) (Ortega \& Gómez, 2009; Parejo et al., 2013).

In match analysis that use observational methodology, the analysis techniques to be used are determined by the objectives pursued and the observational design that supports the study (Anguera et al., 2011). Although the true potential of the observational methodology is obtained from diachronic analysis with data that incorporate order and/or duration (Anguera \& Hernández-Mendo, 2015), the usual synchronous statistical analysis, which look for association relationships between dimensions that provide data categorical, are also relevant to meet the objectives set (O'Donoghue, 2009). The chi-square type statistics have the limitation of contrasting two variables (two-dimensional contingency tables). This limitation, when relating more variables is needed, is usually overcome by repeating the analysis in pairs in the different contingency sub-tables that are generated. However, the loglinear analysis technique does allow the analysis of more than two dimensions, it is much more robust, and it is appropriate from multidimensional contingency tables (Agresti, 2002; Eom \& Schutz, 1992).

The aim of this study was to study efficiency in boy's U16 basketball according to shot position (area of the court where the shot is taken) and last pass position (the position of the player who made the pass leading up to the shot). A second, methodological, aim, was to show how log-linear analysis performed within the framework of an observational methodology (Anguera, 1979) study is a useful tool for this purpose. In a previous study in elite basketball, Alsasua et al. (2019) successfully used log-linear analysis to analyze relationships between the three variables at the core of this study: a) shot position, b) last pass position, and c) shot result.

\section{Method}

We applied a nomothetic, intersessional/intrasessional follow-up, multidimensional observational design (N/F/M) (Anguera et al., 2011). The design was nomothetic as we observed eight teams; it is intersessional and intrasessional follow-up as we analyzed seven matches corresponding to the quarter-finals, semi-finals, and final of the Spanish U16 Basketball Club Championship as well as all relevant behaviors that occurred during each match; and it is multidimensional as different dimensions (criteria), all of which are included in the observation instrument, were studied. The behaviors were both proxemic (i.e., they occurred in different areas of the court) and gestural (i.e., they involved different technical-tactical actions).

\section{Participants}

The participants were U16 boys who played the quarterfinals, semi-finals, and final of the Spanish U16 Basketball Club Championship (2012), which brings together the country's elite in this category. For each of the matches analyzed, we studied all offensive sequences that ended in a shot by the winning team.

\section{Observation instrument}

The observation instrument (Table 1 ) is an adaptation of the SOBL-2 instrument designed by Fernández et al. (2009) to analyze efficiency in basketball. It combines a field format and a category systems. To satisfy the objective of the work, and facilitate the didactic development of the application of the loglinear analysis technique, it has been considered suitable to develop a three-dimensional model. That is why we made two modifications to the original SOBL-2: we grouped all proxemic categories (codes) into a single dimension (area of the court) and classified each completion of sequence category as favorable (basket [Mk], foul received [FR], and basket and foul [A1]) or unfavorable (missed basket [Ms], offensive foul/violation [Vi], and block [BI]). 
Table 1. Observation Instrument

\begin{tabular}{ll|c|c|c}
\hline \multicolumn{1}{c|}{ Dimension } & \multicolumn{1}{c}{ Category (codes) } \\
\hline Area & $\begin{array}{l}\text { Middle of left corridor (ML); Outer left corridor } \\
\text { (OL); Middle of right corridor (MR); Outer right } \\
\text { corridor (OR); Middle of central corridor (MC); } \\
\text { Outer central corridor (OC); paint (P) }\end{array}$ \\
& & \\
\hline Action & $\begin{array}{l}\text { Ball recovery (BR); Defensive rebound (DR); Offensive rebound (OR); Penultimate pass } \\
\text { (P1); Penultimate reception (R1); Last pass (P2); Last reception (R2); New possession } \\
\text { (NP); Shot (Sh) }\end{array}$ \\
\hline $\begin{array}{l}\text { Completion } \\
\text { sequence }\end{array}$ & $\begin{array}{l}\text { Favorable: Basket (Mk); Foul received (FR); Basket and foul (A1). Unfavorable: Missed } \\
\text { basket (Ms); Offensive foul/violation (Vi); Block (B1) }\end{array}$ \\
\hline $\begin{array}{l}\text { Initiation } \\
\text { sequence }\end{array}$ & $\begin{array}{l}\text { Ball in play (BP); Offensive sideline throw-in (OST); Offensive baseline throw-in (OBT); } \\
\text { Opening tip-off (OT); Defensive baseline throw-in (DBT); Defensive sideline throw-in } \\
\text { (DST); Free throw (FT) }\end{array}$ \\
\hline
\end{tabular}

Procedure

The observation instrument was loaded into Match Vision Studio v.3 for data annotation and coding (Castellano et al., 2008). The observation sample was generated by annotating all sequences of play ending in a shot by the winning team. Each sequence comprised the shot and a maximum of five actions leading up to this shot. A maximum of six rows thus was created for each sequence in the dataset. Based on the criteria of Bakeman (1978), the data can be considered type IV, concurrent, and time-based.

\section{Data quality control}

\section{Interobserver agreement}

There have been two observers -with the academic degree of a doctor, proven experience in observational methodology and title of National Basketball coach-in charge of making the records in this study. The observer training process has been carried out from Anguera (2003): 1) Theoretical training in the observation instrument; 2) Theoretical-practical training: in relation to the recording procedure, once the observation instrument has been entered in the Match Vision Studio v.3 recording and coding instrument; 3) Practical training: supervised record of five plays (belonging to a match of the same competition but out of sampling); later autonomous recording of the observers of another five plays; and once a high degree of concordance was obtained (Cohen's kappa> 0.80 ) between the autonomous records of both observers, the training process was considered completed.

The first observer coded $100 \%$ of the sequences in the observation sample while the second observer coded $10 \%$ (Alsasua et al., 2019; Sastre et al., 2021). The agreement between the resulting datasets was measured using Cohen's kappa statistic (Cohen, 1968) in GSEQ (v. 5.1). The kappa statistics for the different match datasets were 0.89 for FC Barcelona-Torrelodones (the first team is the winning team, i.e., the team observed), 0.90 for Cajasol-Easo, 0.81 for Peixe-Joventut, 0.83 for Unicaja-Endesa, 0.86 for Cajasol-FC Barcelona, 0.89 for Peixe-Unicaja, and 0.82 for Cajasol-Peixe.

\section{Generalizability of results}

To further confirm the reliability of the data, we performed a generalizability theory analysis (Cronbach et al., 1972) in SAGT (v. 1.0) (Ramos et al., 2012), which involved estimating the generalizability coefficients obtained in the general linear model for the design categories/matches, where matches was the instrumentation facet.

Overall, $92.9 \%$ of the variability was explained by the categories facet, $1.4 \%$ by the matches facet, and $5.7 \%$ by the interaction between the two facets. The relative generalizability coefficient obtained $(e 2=0.991)$ attests to the homogeneity of the datasets and the high level of generalizability of our results.

\section{Data analysis}

For the log-linear analysis, we analyzed the relationship between three dimensions: position of shot, position of pass leading up to the shot, and shot result. The purpose of loglinear analysis is to select the most parsimonious model capable of explaining the distribution of frequencies in the contingency table with the fewest effects possible (Agresti, 2002; López-Roldán \& Fachelli, 2015).

The process involved three steps. In the first step, the most parsimonious model was selected using the backward elimination method in SPSS (v. 19.0). This procedure produces the simplest possible model by removing, one by one, nonsignificant effects while maintaining the hierarchy of the model (Pérez, 2013). In other words, if a model includes higher-order parameters, then all the lower-order parameters must be included (López-Roldán \& Fachelli, 2015). The saturated model, i.e., the model containing all possible effects, is entered into SPSS, which progressively removes all nonsignificant higher-order interactions until the simplest model (i.e., the model in which the elimination of another effect would alter the goodness of fit) is achieved (Pérez, 2013). The second step was to estimate the parameters that comprised the most parsimonious model. SPSS (v. 19.0) contains a general log-linear feature that estimates the

Cultura, Ciencia y Deporte | AÑo 2022 | volumen $17 \mid$ NUM. 51 | España | PÁG. 105 A 112 | ISSN: 1696-5043 
magnitude of each effect in the selected model (Valldecabres et al., 2022). So that it can do this, it is necessary to select a dummy variable (reference category) for each dimension. In our case, we chose outer central corridor for last pass position, shot from paint position, and favorable outcome for shot result. The resulting parameters are expressed as neperian logs, and as such, the exponential function (or antilogarithm) of the estimated parameters are the equivalent of odds and odds ratios for the different categories in the dimensions. These logs indicate the influence (magnitude) of the different effects. In the third and final step, the effects of significant parameters were interpreted in the context of our study.
Results

The simplest model generated in step 1 of the log-linear analysis was a conditional independence model (LópezRoldán \& Fachelli, 2015) in which two of the dimensions (last pass position and shot position) were associated independently of the third dimension (shot result). The interaction between shot position and result were not influenced by last pass position. Table 2 shows the estimations for the significant model parameters from step 2 of the loglinear analysis.

Table 2. Estimation of significant parameters in selected model

\begin{tabular}{lcccc}
\hline Parameter (variable/category) & Estimate $(\boldsymbol{\lambda})$ & $\begin{array}{c}\text { Sig. } \\
(>\mathbf{0 0 5})\end{array}$ & $\begin{array}{c}\text { Exponential } \\
(\boldsymbol{\lambda})\end{array}$ & $\begin{array}{c}\mathbf{1} / \\
\mathbf{\operatorname { e x p }}(\boldsymbol{\lambda})\end{array}$ \\
\hline Last pass from the outer right corridor & 0.981 & 0.001 & 2.667 & 0.375 \\
\hline Last pass from paint & 1.006 & 0.001 & 2.375 & 0.365 \\
\hline Shot from middle of left corridor & 1.030 & 0.001 & 2.801 & 0.357 \\
\hline Shot from outer right corridor & -1.104 & 0.018 & 0.332 & 3.016 \\
\hline Shot from outer left corridor & -1.330 & 0.017 & 0.264 & 3.781 \\
\hline Shot from middle central corridor & -1.492 & 0.005 & 0.225 & 4.446 \\
\hline $\begin{array}{l}\text { Last pass from paint * shot from outer right } \\
\text { corridor }\end{array}$ & -4.395 & 0.002 & 0.012 & 81.045 \\
\hline $\begin{array}{l}\text { Last pass from paint * shot from outer left } \\
\text { corridor }\end{array}$ & -2.615 & 0.021 & 0.073 & 13.667 \\
\hline $\begin{array}{l}\text { Shot from outer right corridor * unfavorable shot } \\
\text { result }\end{array}$ & 1.015 & 0.001 & 2.759 & 0.362 \\
\hline $\begin{array}{l}\text { Shot from outer central corridor * unfavorable } \\
\text { shot result }\end{array}$ & 0.991 & 0.002 & 2.694 & 0.371 \\
\hline $\begin{array}{l}\text { Shot from middle of left corridor * unfavorable } \\
\text { shot result }\end{array}$ & 2.358 & 0.027 & 10.570 & 0.0095 \\
\hline
\end{tabular}

Results are interpreted using the exponential $(\lambda)$ value shown in the third column of Table 2 . Values $>1$ indicate that a given category is significantly more likely to occur than the reference category. For example, the $\exp (\lambda)$ value in the first row of Table 2, 2.667, indicates that a pass leading up to a shot is 2.667 times more likely to be made from the outer right corridor than from the outer central corridor. Values $<1$ indicate that extent to which a given category is less likely to occur compared with the reference category. As indicated by the value in the fifth row of Table 2, a shot from the outer right corridor is 0.332 times less likely to occur than one from the paint. To simplify matters in the discussion of results, we have inverted $\exp (\lambda)$ values $<1$ to $1 / \exp (\lambda)$ (column 4 of Table $2)$. This inverse value indicates how more likely it is that the reference category will occur compared with a given category. Taking the previous example from the fifth row of Table 2, the $\exp (\lambda)$ indicates that a shot from the paint is 3.016 times more likely than one from the outer right corridor.

\section{Discussion}

The substantive objective of this work is to study the effectiveness in basketball sub 16 depending on the area of the court from where the last pass and the shot are made. The methodological aim of this study was to illustrate the possibilities offered by log-linear analysis within the framework of observational methodology (Anguera, 1979). Log-linear analysis permits the simultaneous exploration of higher-order interactions between dimensions formed by categorical variables (Agresti, 2002). It is therefore suitable for analyzing multidimensional contingency tables (Eom \& Schutz, 1992), i.e., tables with $>2$ dimensions. In this study, we used log-linear analysis to analyze efficiency in U16 basketball from the perspective of three dimensions (last pass position, shot position, and shot result) and their respective categories. As a limitation of the loglinear analysis technique, it is stated that, as the number of incorporated dimensions increases, the interpretation of the results becomes more complex.

The results obtained from the log-linear analysis carried out show that the most parsimonious hierarchical model -capable of explaining the distribution of cell counts in this three-way model featuring the fewest effects possible (Lozares \& López-Roldán, 1998)- selected through the backward procedure which is that of conditional independence: the association between the area of the court from which the last pass is made and the area from which the shot is made is independent from the consequence of the shot; and the association between the area from which the shot is made and the consequence of the shot is independent of the area from which the last pass is made. 
The first-order effects show that passes immediately preceding a shot are more likely to come from the outer right corridor $(-\exp (\lambda)=2.667)$, the paint $(\exp (\lambda)=2.375)$, or the middle of the left corridor $(\exp (\lambda)=2.801)$ than from the outer central corridor. In a recent study of top teams from the Spanish men's professional league (ACB), Alsasua et al. (2019) also found that shots were more likely to be preceded by a pass from the paint than from the outer central corridor. These results are consistent with findings showing that the outer central corridor is where passes are least likely to be made to a shooter (Fernández et al. 2009) and where other offensive strategies are more recommendable (Lamas et al., 2010). Some authors, however, recommend using this part of the court for distributing the ball and even for passing the ball to a player open for a shot (Ortega \& Gómez 2009; Refoyo et al., 2009; Romaris et al., 2012). The lower use of the central pick and roll in sub 16 basketball may be behind the lower probability of the last pass being made from the outer central corridor.
Our results for first-order effects (Figure 1) also show that shots are more likely to taken from inside the paint than from the outer right corridor $(1 / \exp (\lambda)=3.016)$, the outer left corridor $(1 / \exp (\lambda)=3.781)$, or the middle of the central corridor (1/exp $(\lambda)=3.378)$. Alsasua et al. (2019) also found that ACB players were more likely to shoot from the paint than from either the left outer corridor or the middle of the central corridor. Most studies have found that the paint is where most shots are taken (Fernández et al., 2009; Ibáñez et al., 2009; Mexas et al., 2005). Exceptions include shots immediately following a direct screen (Muñoz et al., 2015). Nonetheless, Alsasua et al. (2019) found that shots taken from the paint by ACB players were more likely to be preceded by a pass from the outer central corridor than from the outer right corridor. The greater use of fast and counter play in formation categories (Monteiro et al., 2013) contributes to the greater probability that shots will be made near the basket.

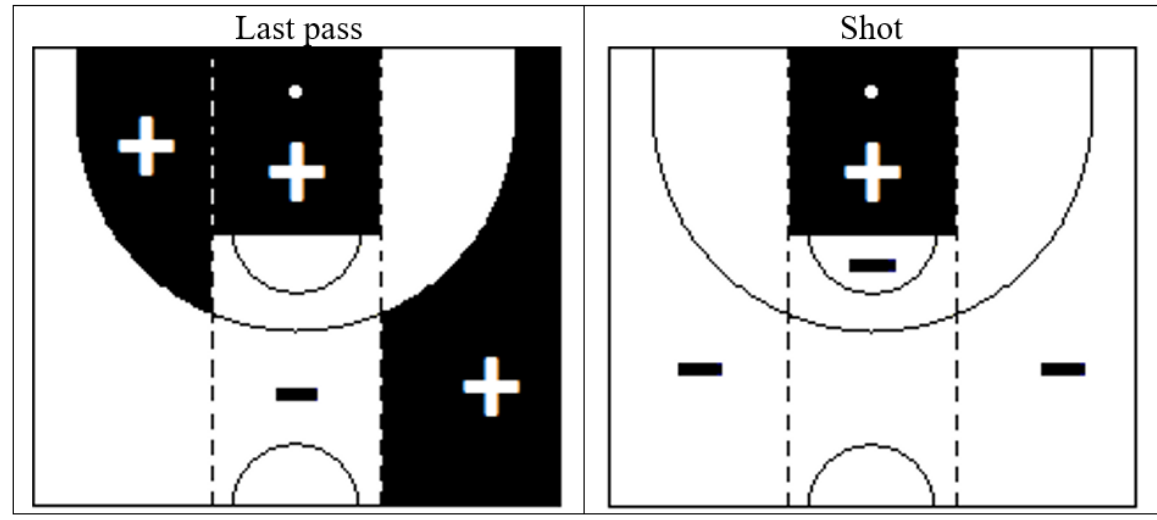

Figure 1. Graph showing first-order effects. Passes leading up to a shot are more likely to be made from the outer right corridor than from the middle of the left corridor and from the paint than from the outer central corridor (left). Shots, in turn, are more likely to be taken from the paint than from the outer left corridor, the outer right corridor, or the middle of the central corridor (right)

The second-order effects corresponding to the interaction between last pass position and shot position (Figure 2) also show that a pass from the paint is more likely to result in a shot from the same area than from either the outer right $(1 / \exp (\lambda)=81.045)$ or outer left $(1 / \exp (\lambda)=13.667)$ corridor. Similarly, Alsasua et al. (2019) found that shots within the paint were more likely to be preceded by a pass from the paint than from the outer right corridor in ACB matches. This association between passes and shots within the paint is interesting as it defies the minimum passer-receiver distance recommended by Ortega and Gómez (2009) and Fewell et al. (2012). In a T-pattern analysis of actions following direct screens in two ACB tournaments, Serna et al. (2017) detected a significant association between passes between players in the paint. Alsasua et al (2019) also found that passes from ACB players located in the outer left or right corridor or in the middle of the right corridor were more likely to end in a shot from the paint. The higher probability of this pass in U16 basketball may be related to drive and kick situations against less structured assist defenses that allow this type of inside pass after penetration. 


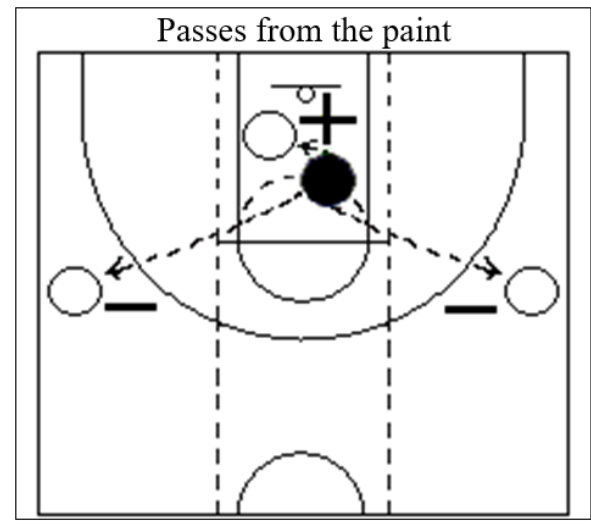

Figure 2. Second-order effects of the association between last pass position and shot position showing the likelihood of a shot according to where the pass was made from

Second-order effects corresponding to the interaction between shot position and shot result show that shots are more likely to have an unfavorable outcome when taken from the outer right corridor $(\exp (\lambda)=2.759)$, the outer central corridor $(\exp (\lambda)=2.694)$, or the middle of the central corridor $(\exp (\lambda)=10.570)$. This finding partially coincides with reports by Alsasua et al. (2019) that shots taken by ACB players were more likely to be unsuccessful when taken from the outer right or outer central corridors. They are also consistent with reports that shots taken from the outer right corridor are most likely to have an unfavorable outcome (Fernández et al.,
2009; Lapresa et al., 2014). Fernández and Piñar (2017), on comparing winning and losing U14 teams found that shots taken from the middle of the central corridor were missed more than shots taken elsewhere. Finally, it is worth noting that in their study of top-performing ACB teams, Alsasua et al. (2019) did not find that shots were more likely to have an unfavorable outcome in this part of the court. The less elaboration of the game in basketball sub 16 before increasingly organized defenses (Erculj \& Strumbelj, 2015) may be behind the less effective shooting from the zones reflected in figure 3.

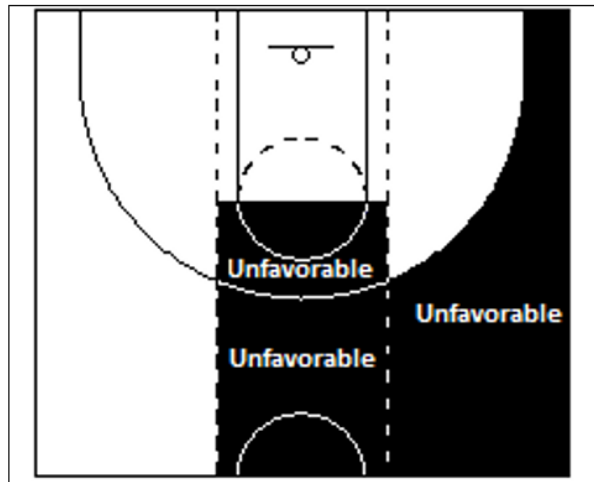

Figure 3. Second-order effects of the association between shot position and shot result showing (in black) where shots are more likely to have an unfavorable outcome

\section{Conclusion}

Relevant studies that contribute to a longitudinal programming of the content in the root sport -basketball in our case- are relevant, as milestones in a roadmap -extracted from reference teams of the corresponding age categoriesthat those involved in training basketball they should take into account (Lapresa et al., 2018). Log-linear analysis is a useful technique for analyzing successful and unsuccessful actions in basketball and in this particular case for detecting associations between last pass position, shot position, and shot result. In sub 16 basketball, the lower probability that the pre-throw pass is made from the outer right corridor than from the middle of the left corridor and from the paint than from the outer central corridor has been found. The pitches made in this category sub 16 are more likely to be taken from the paint than from the outer left corridor, the outer right corridor, or the middle of the central corridor. It has also been obtained that a pass from the paint is more likely to result in a shot from the same area than from either outer corridor. Finally, the middle of the left corridor, the outer central corridor and the outer right corridor have been characterized as the least effective positions for a successful shot in the sub 16 category.

\section{References}

Agresti, A. (2002). Categorical data analysis. New Jersey: John Wiley \& Sons.

Alsasua, R., Lapresa, D., Arana, J., Anguera, M.T., \& Garzón, B. (2018). Successful and unsuccessful offensive sequences

$$
\text { Cultura, Ciencia y Deporte | AÑ̃o } 2022 \text { | volumen } 17 \text { | NUM. } 51 \text { | España | PÁG. } 105 \text { A } 112 \text { | ISSN: 1696-5043 }
$$


ending in a shot in professional and elite under-16 basketball. Journal of Human Kinetics, 64(1), 147-159. https: //doi.org/10.1515/hukin-2017-0191

Alsasua, R., Lapresa, D., Arana, J., \& Anguera, M.T. (2019). A log-linear analysis of efficiency in elite basketball applied to observational methodology. International Journal of Sports Science \& Coaching, 14 (3), 363-371. https://doi.org/10.1177 /1747954119837819

Anguera, M.T. (1979). Observational Typology. Quality \& Quantity. European-American Journal of Methodology, 13(6), 449-484.

Anguera, M.T. (2003). La observación. En C. Moreno Rosset (Ed.), Evaluación psicológica. concepto, proceso y aplicación en las áreas del desarrollo y de la inteligencia [Psychological evaluation. Concept, process and application in development and intelligence areas] (pp. 271-308). Madrid: Sanz y Torres.

Anguera, M.T. \& Hernández-Mendo, A. (2015). Técnicas de análisis en estudios observacionales en ciencias del deporte [Data analysis techniques in observational studies in sport sciences]. Cuadernos de Psicología del Deporte, 15(1), 13-30. https://doi.org/10.4321/S157884232015000100002

Anguera, M.T., Blanco-Villaseñor, A., Hernández-Mendo, A., \& Losada, J.L. (2011). Diseños observacionales: ajuste y aplicación en psicología del deporte [Observational designs: adjustment and application in sport psychology]. Cuadernos de Psicología del Deporte, 11(2), 63-76.

Bakeman, R. (1978). Untangling streams of behavior: Sequential analysis of observation data. En G.P. Sackett (Ed.), Observing Behavior (Vol. 2, pp. 63-78). Baltimore: University of Park Press.

Castellano, J., Perea, A., Alday, L., \& Hernández-Mendo, A. (2008). Measuring and observation tool in sports. Behavior Research Methods, 40(3), 898-905. https://doi.org/10.3758/ BRM.40.3.898

Cohen, J. (1968). Weighted Kappa: nominal scale agreement with provision for scaled disagreement or partial credit. Psychological Bulletin, 70, 213-220. https://doi.org/10.1177/ 001316446002000104

Cronbach, L.J., Gleser, G.C., Nanda, H., \& Rajaratnam, N. (1972). The dependability of behavioral measurements: theory of generalizability for scores and profiles. New York: Wiley.

Eom, H.J., \& Schutz, R.W. (1992). Transition play in team performance of volleyball: a log-linear analysis. Research Quarterly for Exercise and Sport, 63(3), 261-269. https://doi. org/10.1080/02701367.1992.10608741

Erculj, F., \& Strumbelj, E. (2015) Basketball Shot Types and Shot Success in Different Levels of Competitive Basketball. PLoS ONE, 10(6). https://doi.org/10.1371/journal.pone.0128885

Fernández, J., Camerino, O., Anguera, M.T., \& Jonsson, G.K. (2009). Identifying and analyzing the construction and effectiveness of offensive plays in basketball by using systematic observation. Behavior Research Methods, 41(3), 719-730. http://dx.doi.org/10.3758/BRM.41.3.719

Fernández, J.A., \& Piñar, M.I. (2017). Estudio de las fases de ataque en baloncesto infantil masculino: diferencias entre ganadores y perdedores [Study of the attack phases in 14and-under male basketball: differences between winners and losers]. Cuadernos de Psicología del Deporte, 17(3), 207-216.

Fewell, J.H., Armbruster, D., Ingraham, J., Petersen, A., \& Waters, J.S. (2012). Basketball Teams as Strategic Networks.
PLOS ONE, 7(11), e47445. https://doi.org/10.1371/journal.p one.0047445

García, J., Ibáñez, S.J., Martínez de Santos, R., Leite, N., \& Sampaio, A.J. (2013). Identifying Basketball Performance Indicators in Regular season and Playoff Games. Journal of Human Kinetics, 36, 161-168. https://doi.org/10.2478/hukin -2013-0016

Gómez, M.A., Lorenzo, A., Barakat, R., Ortega, E., \& Palao, J.M. (2008). Differences in Game-Related Statistics of Basketball Performance by Game Location for Men's Winning and Losing Teams. Perceptual and Motor Skills, 106(1), 43-50. htt ps://doi.org/10.2466/pms.106.1.43-50

Gómez, M.A., Lorenzo, A., Ibáñez. S.J., \& Sampaio, J. (2013) Ball possession effectiveness in men's and women's elite basketball according to situational variables in different game periods. Journal of Sports Sciences, 31(14), 1578-1587. https://doi.org/10.1080/02640414.2013.792942

Ibáñez, S.J., García, J., Feu, S., Parejo, I., \& Cañadas, M. (2009). La eficacia del lanzamiento a canasta en la NBA: Análisis multifactorial [Shot efficacy in the NBA: A multifactorial analysis]. Cultura, Ciencia y Deporte, 4(10), 39-47. https://do i.org/10.12800/ccd.v4i10.132

Ibáñez, R., Lapresa, D., Arana, J., Camerino, O., \& Anguera, M.T. (2018). Observational Analysis of the Technical-Tactical Performance of Elite Karate Contestants. Cultura, Ciencia y Deporte, 13(37), 61-70. https://doi.org/10.12800/ccd.v13i37 .1039

Izquierdo, J.M., Pedauga, L.E., Pardo-Fanjul, A., \& Redondo, J.C. (2021). Marginal contribution of game statistics to probability of playing playoff at elite basketball leagues. Cultura, Ciencia y Deporte, 16(49), 433-442. https://doi.org/1 0.12800/ccd.v16i49.1586

Lamas, L., De Rose, J., Santana, F., Rostaiser, E., Negretti, L., \& Ugrinowitsch C. (2010). Space creation dynamics in basketball offence: validation and evaluation of elite teams. International Journal of Performance Analysis in Sport, 11(1), 71-84. https://doi.org/10.1080/24748668.2011.11868530

Lapresa, D., Anguera, M.T., Alsasua, R., Arana, J., \& Garzón, B. (2013). Comparative analysis of T-patterns using real time data and simulated data by assignment of conventional durations: the construction of efficacy in children's basketball. International Journal of Performance Analysis in Sport, 13(2), 321-339.

Lapresa, D., Alsasua , R., Arana , J., Anguera, M. T., \& Garzón, B. (2014). Análisis observacional de la construcción de las secuencias ofensivas que acaban en lanzamiento en baloncesto de categoría infantil [Observational analysis of the construction of offensive sequences that end in a shot in youth basketball]. Revista de Psicología del Deporte, 23(2), 365-376.

Lapresa, D., Del Río, A., Arana, J., Amatria, M. \& Anguera, M.T. (2018): Use of effective play-space by U12 FC Barcelona players: an observational study combining lag sequential analysis and T-pattern detection. International Journal of Performance Analysis in Sport, 18(2), 293-309. https://doi.or g/10.1080/24748668.2018.1475195

López-Roldán, P. \& Fachelli, S. (2015). Metodología de la Investigación Social Cuantitativa [Methodology of Quantitative Social Research]. Bellaterra: Universidad Autónoma de Barcelona.

Lorenzo, A., Gómez, M.A., Ortega, E., Ibáñez, S.J., \& Sampaio, J. (2010). Game related statistics which discriminate between winning and losing under- 16 male basketball games. Journal of Sports Science and Medicine, 9, 664-668.

Cultura, Ciencia y Deporte $\mid$ AÑO 2022 | voLUMEN 17 | NUM. 51 | España | PÁG. 105 A 112 | ISSN: 1696-5043 
Lozares, C., \& López-Roldán, P. (1998). La complementariedad del log-lineal y del análisis de correspondencias en la elaboración y el análisis de tipologías [Complementary use of loglinear and correspondence analyses in the development and analysis of typologies]. Papers: Revista de Sociologia, 55, 79-93.

Mexas, K., Tsitskaris, G., Kyriakou, D., \& Garefis, A. (2005). Comparison of effectiveness of organized offences between two different championships in high level basketball. International Journal of Performance Analysis in Sport, 5(1), 72-82. https://doi.org/10.1080/24748668.2005. 11868317

Monteiro, I., Tavares, F., \& Santos, A. (2013). Comparative study of the tactical indicators that characterize the fast break in male and female under-16 Basketball teams. Revista de Psicología del Deporte, 22(1), 239-244.

Muñoz, V., Serna, J., Daza, G., \& Hileno, R. (2015). Influence of Direct Blocking and One-on-one on Successful Shooting in Basketball. Apunts. Educación Física y Deportes, 119, 80-86. https://doi.org/10.5672/apunts.2014-0983.es.(2015 /1). 119.05

O'Donoghue, P. (2009). Research methods for sports performance analysis. London: Routledge.

Ortega, E., \& Gómez, M.A. (2009). Metodología observacional en baloncesto de formación [Observational methodology in grassroots basketball]. Murcia: Diego Marín Librero-Editor.

Ortega, E., Palao, J.M., Gómez, M.A., Lorenzo, A., \& Cárdenas, D. (2007). Analysis of the efficacy of possessions in boys' 16and-under basketball teams: differences between winning and losing teams. Perceptual and Motor Skills, 104, 961-964. https://doi.org/10.2466/pms.104.3.961-964

Oudejans, R. R. D., Karamat, R. S., \& Stolk, M. H. (2012). Effects of Actions Preceding the Jump Shot on Gaze Behavior and Shooting Performance in Elite Female Basketball Players. International Journal of Sports Science \& Coaching, 7(2), 254267. https://doi.org/10.1260/1747-9541.7.2.255

Parejo, I., García, A., Antúnez, A., \& Ibáñez, S.J. (2013). Differences in performance indicators among winners and losers of group A of the spanish basketball amateur league (EBA). Revista de Psicología del Deporte, 22 (1), 257-261.

Pérez, C. (2013). Análisis multivariante de datos: aplicaciones con IBM SPSS, SAS y STATGRAPHICS [Multivariate data analysis: applications with IBM SPSS, SAS and STATGRAPHICS]. Madrid: Ibergarceta.

Piñar, M.I., Estévez-López, F., Ortega, V., Conde, J., Alarcón, F., \& Cárdenas, D. (2014). Characteristics of attack phases in boys' 14-and-under basketball competition. Revista Internacional de Medicina y Ciencias de la Actividad Física y el Deporte, 14(54), 265-278.

Refoyo, I., Romaris, I.U., \& Sampedro, J. (2009). Analysis of men's and women's basketball fast-breaks. Revista de Psicología del Deporte, 18(3), 439-444.

Ribeiro, H.V., Mukherjee, S., \& Zeng, X.H. (2016). The Advantage of Playing Home in NBA: Microscopic, TeamSpecific and Evolving Features. PLoS ONE 11(3). https://doi. org/10.1371/journal.pone.0152440

Romaris I.U., Refoyo, I., \& Coterón, J. (2012). La finalización de las posesiones en baloncesto: estudio de la acción de finalización [The completion of the possessions in basketball: study of the completion action]. Cuadernos de Psicología del Deporte, 12(supple), 45-49.

Sampaio, J., Lago, C., \& Drinkwater, E.J. (2010). Explanations for the United States of America's dominance in basketball at the Beijing Olympic Games (2008). Journal of Sports Sciences, 28(2), 147-152. https://doi.org/10.1080/026404109033804 86

Sastre, V., Lapresa, D., Arana, J., Ibáñez, R. \& Anguera, M.T. (2020). Observational analysis of technical-tactical performance in initiation to combat in karate, International Journal of Performance Analysis in Sport, 21(1), 126-138. http s://doi.org/10.1080/24748668.2020.1853450

Serna, J., Muñoz, V., Hileno, R., Solsona, E., \& Sáez, U. (2017). Patrones temporales iniciados con bloqueo directo o uno contra uno en baloncesto [T-Patterns initiated with ball screen or one-on-one in basketball]. Revista de Psicología del Deporte, 26(3), 81-86.

Simovic, S., Komic, J., Guzina, B., Pajic, Z., Karalic, T., \& Pasic, G. (2021). Difference-based analysis of the impact of observed game parameters on the final score at the FIBA Eurobasket Women. Journal of Human Sport and Exercise, 16(2), 373-387. https://doi.org/10.14198/jhse.2021.162.12

Simovic, S., Matkovic, B., Mijanovi, M., Kocic, M., \& Vojvodic, M. (2012). Structure of efficiency factor at XIII, XIV, XV and XVI World Championship in basketball. Journal of Human Sport and Exercise, 7(2), 527-543. https://doi.org/10.4100/jhse.20 12.72.16

Valldecabres, R., de Benito, A.M., Losada, J.L., \& Casal, C.A. (2022). Badminton World Championship stress zones and performance factors: The key to success through log-linear analysis .Journal of Human Sport and Exercise, 17(1), 10-21. https://doi.org/10.14198/jhse.2022.171.02

\section{Acknowledgement}

The authors gratefully acknowledge the support of a Spanish government subproject Integration ways between qualitative and quantitative data, multiple case development, and synthesis review as main axis for an innovative future in physical activity and sports research [PGC2018-098742-B-C31] (2019-2021) (Ministerio de Ciencia, Innovación y Universidades, Programa Estatal de Generación de Conocimiento y Fortalecimiento Científico y Tecnológico del Sistema $1+D+i)$, that is part of the coordinated project New approach of research in physical activity and sport from mixed methods perspective (NARPAS_MM) [SPGC201800X098742CV0]. In addition, the authors thank the support of the Generalitat de Catalunya Research Group, Grup de recerca i innovació en dissenys (GRID), Tecnología i aplicació multimedia i digital als dissenys observacionals [Grant number 2014 SGR 971]. Also, this study was funded by grants from the University of La Rioja.

$$
\text { Cultura, Ciencia y Deporte | AÑ̃o } 2022 \text { | volumen } 17 \text { | NUM. } 51 \text { | España | PÁG. } 105 \text { A } 112 \text { | ISSN: 1696-5043 }
$$

